\title{
NANOCELLULOSE OBTAINED MECHANICALLY BY DIFFERENT COLLOID GRINDING INTENSITIES
}

\author{
Marina Stygar Lopes ${ }^{1 *}$, Daniele Cristina Potulski² ${ }^{2}$ Lívia Cássia Viana ${ }^{3}$, Mayara Elita Carneiro ${ }^{4}$, Graciela Inês \\ Bolzon de Muniz ${ }^{5}$, Alan Sulato de Andrade ${ }^{6}$ \\ 1* Federal University of Paraná, PhD student in the Forest Engineering Graduate Program, Curitiba, PR, Brazil - marinastygar@ gmail.com \\ ${ }^{2}$ Federal University of Paraná, Department of Forest Engineering and Technology, Curitiba, Paraná, Brazil - danielepotulski@ gmail.com, \\ ${ }^{3}$ licvianna@gmail.com, ${ }^{4}$ mayaraecarneiro@gmail.com, ${ }^{5}$ gbmunize@ufpr.br, \\ ${ }^{6}$ alansulato@gmail.com
}

Received for publication: 02/04/2018 - Accepted for publication: 28/06/2019

\begin{abstract}
Resumo
Nanocelulose obtida mecanicamente por diferentes intensidades em moinho coloidal. Pesquisas com nanocelulose têm revelado um material com diversas possibilidades de aplicações e propriedades atraentes para a criação de novos produtos sustentáveis. Este trabalho deve como objetivo avaliar a celulose nanofibrilada de Eucalyptus sp. produzida a partir de diferentes intensidades no moinho coloidal. Polpa Kraft deslignificada de Eucalyptus sp. foi utilizada para obtenção da celulose nanofibrilada por processo mecânico no moinho coloidal utilizando 2, 10 e 20 passes. As estruturas celulósicas foram observadas por imagens de microscopia eletrônica de varredura e de transmissão. Foram produzidos três filmes por tratamento utilizados para determinar os índices de cristalinidade. Já a análise de viscosidade avaliou a influência das intensidades do processo sobre a celulose nanofibrilada. As análises microscópicas mostraram que o tratamento mecânico gerou a redução no diâmetro das fibras, promovendo a exposição das microfibrilas, para todos os tratamentos avaliados. As nanofibrilas apresentaram diâmetro médio de aproximadamente $30 \mathrm{~nm}$ e não foram observados diferenças na conformação e dimensões das estruturas para os diferentes números de passes. O processo mecânico para obtenção da celulose nanofibrilada foi responsável pela queda nos valores de cristalinidade e viscosidade da celulose nanofibrilada quando comparada a celulose original. Os valores indicaram que a redução foi maior com o aumento da intensidade do processo mecânico.
\end{abstract}

Palavras-chave: celulose, nanotecnologia, filme nanoestruturado, densidade, cristalinidade.

\begin{abstract}
Recent advances in nanocellulose technology have enabled production of materials for various applications with attractive properties. The aim of this work was to analyze the nanofibrillated cellulose of Eucalyptus sp. obtained by different grinding intensities. Delignified Eucalyptus sp. kraft pulp was used to obtain the nanofibrillated cellulose in the mechanical grinding process, with 2, 10 and 20 passes. Images were captured by scanning and transmission electron microscopy to observe cellulose structures. For each mechanical treatment, three films were produced, which were used to evaluate the crystallinity index. Viscosity measurement evaluated the influence of mechanical treatment on nanofibrillated cellulose. Microscopic analysis showed that the mechanical process promoted fiber defibrillation, resulting in the exposure of microfibrils in all treatments evaluated. Differences were not verified in the conformation and dimensions of the structures for the different numbers of passes, and the nanofibrils presented average diameter of approximately $30 \mathrm{~nm}$. The mechanical process to obtain the nanofibrillated cellulose reduced of the crystallinity index and the viscosity of the nanofibrillated cellulose compared to cellulose before processing. The average particle size declined with rising number of grinder passes.

Keywords: cellulose, nanotechnology, nanostructured film, density, crystallinity.
\end{abstract}

\section{INTRODUCTION}

Cellulose is a renewable polymer abundantly found in nature that has been widely studied for its properties such as low cost, biodegradability and potential application in various areas (NAKAGAITO et al., 2009). One of the products obtained from cellulose, through mechanical, chemical, physical and/or biological processes, is nanocellulose, which has potential for application in new products in many areas, such as pulp and paper (BALEA et al., 2018), packaging (HERRERA et al., 2016), composites (CHING et al., 2015; KARGARZADEH et al., 2017) and drugs (ELIZONDO et al., 2012).

Nanofibrillated cellulose (NFC) is a type of nanocellulose obtained from cellulosic pulp using mechanical processes, and may or may not undergo some type of chemical or enzymatic treatment. Cellulose nanofibrils have

FLORESTA, Curitiba, PR, v. 50, n. 1, p. 897 - 904, jan/mar 2020

Lopes, M. S. et.al.

ISSN eletrônico 1982-4688

DOI: $10.5380 /$ rf.v50 i1.58690 
crystalline regions alternating with amorphous regions in their structure, with approximate length in micrometers and diameters that can vary from 1 to $100 \mathrm{~nm}$ (BRINCHI et al., 2013; ABDUL KHALIL et al., 2014).

One example of the methods for obtaining NFC is by mechanical defibrillation using a grinder. The grinder consists of a rotating disk and a fixed disk with an adjustable opening between them. Through mechanical contact, the cellulose fibers are defibrillated by the shear forces generated by the silicon carbide stones (POTULSKI et al., 2016). In this way, there is exposure of microfibrils and microfibril aggregates of cellulose that have diameters of tens of nanometers, producing a material called nanofibrillated cellulose (MISSOUM et al., 2013).

In the pulp and paper sector, nanofibrillated cellulose has been studied as an additive to improve the physical and mechanical properties of different paper types. Research shows that the addition of nanofibrillated cellulose in small percentages results in increased paper density and up to $100 \%$ increase in tensile strength (VIANA et al., 2018).

In function of its unique characteristics, such as low thermal expansion, excellent mechanical and optical properties, high strength, high rigidity and low weight, NFC has been evaluated for the development of nanostructured films for application in special and functional packaging, especially in the food industry (BRODIN et al., 2014; FRANCO et al., 2019).

NFC's versatility increases its application, making it a promising material for investments in research and development. There is a wide range of known applications of nanofibrillated cellulose, but there are still many likely uses that remain unknown or little explored. Variations in the parameters of the NFC production process, different lignocellulosic sources and the possibility of combining this material are factors that still need to be studied.

Regarding planted forest species, the Eucalyptus genus stands out in Brazil, given the high productivity rates and good adaptation to much of the country's territory. The wood is mainly applied in the pulp and paper industry.

Therefore, the objective of this work was to evaluate the nanofibrillated cellulose of Eucalyptus $s p$. obtained by different grinding intensities.

\section{MATERIAL AND METHODS}

\section{Obtaining Nanofibrillated Cellulose}

Delignified kraft cellulose pulp (Kappa 3.5) from Eucalyptus sp. was initially dispersed using a disintegrator for five minutes, thus obtaining a suspension of homogenized fibers. One portion of the pulp was applied for direct sheet formation (control treatment: 0 passes) and another portion was used to obtain nanofibrillated cellulose.

The ground nanofibrillated cellulose was obtained using a frequency of $1500 \mathrm{rpm}$ and a kraft pulp concentration of $1 \%$ (diluted with water). The material was submitted to different mechanical processing intensities (2, 10 and 20 grinder passes), and from each treatment samples were taken to make the films and characterize the material.

\section{Preparation of nanofibrillated cellulose films}

The NFC films, produced from 2, 10 and 20 grinder passes, were produced by depositing the material on a nylon mesh with the aid of a vacuum pump to eliminate excess water. After filtration, the films were dried in a paper machine with a temperature of $90^{\circ} \mathrm{C}$ and constant pressure of $80 \mathrm{KPa}$. Sheets were also made from the raw cellulose pulp ( 0 passes) under the same conditions as nanocellulose films.

For each treatment $(0,2,10$ and 20 passes), three films were produced, totaling 12 films, which were conditioned in a climate-controlled room with temperature of $23 \pm 2{ }^{\circ} \mathrm{C}$ and a relative humidity of $50 \pm 2 \%$. Subsequently, the samples were used to determine the crystallinity index. The cellulose pulp sheets were also analyzed by scanning electron microscopy (SEM).

\section{Microscopic characterization}

In order to visualize the dimensions and morphology of the fibers of the kraft cellulose (control), scanning electron microscopy (SEM) was performed in an FEI - Quanta 450 FEG microscope. In turn, the characterization of nanofibrillated cellulose structures and dimensions was performed by transmission electron microscopy (TEM) using a JEOL JEM 1200EX-II transmission electron microscope with resolution of $0.5 \mathrm{~nm}$. The images were acquired after depositing a drop of nanofibrillated cellulose aqueous solution in the sample holder and drying at room temperature to form a film. 


\section{Crystallinity index}

The index was determined before and after the grinder defibrillation process. A Shimadzu XRD-7000 Xray diffractometer was used together with the XRD-6100/7000 v 5.0 software. The sweep speed adopted was $1 \%$ min, ranging from 3 to $45^{\circ}, \mathrm{Cu}-\mathrm{K} \alpha$ radiation with $0.155418 \mathrm{~nm}$ wavelength and $40 \mathrm{kV}$ voltage with $20 \mathrm{~mA}$ current. For each treatment, three crystallinity index values were obtained, which were determined with the method suggested by Segal et al. (1959).

\section{Viscosity}

To this analysis for cellulose and CNF samples, cupriethylenediamine (CED) was used for dissolution, followed by measurement with a capillary viscometer according to TAPPI T $220 \mathrm{om}-01$. To evaluate the effect of mechanical defibrillation on viscosity, three values were obtained per treatment.

\section{Statistical analysis}

The crystallinity and viscosity index values obtained were subjected to analysis of variance with comparison of means by the Tukey test at $5 \%$ probability. Previously, the Grubb test was performed to identify outliers and the normality test, and Bartlett's test to determine homogeneity of variances. All the tests were performed with the Statgraphics Centurion XVI® software, considering 5\% significance.

\section{RESULTS}

Nanofibrillated cellulose and films

After the passage of the kraft pulp through the grinder, the material acquired a gel appearance (Figure 1), as already verified in other works (BESBES et al., 2011). Figure 1B shows images of nanostructured films.
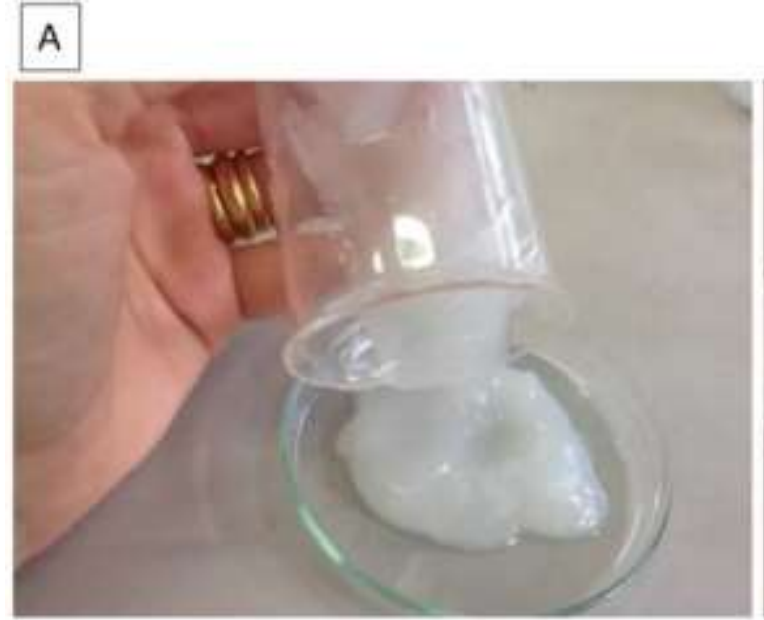

\section{B}



Figure 1. A) Nanofibrillated cellulose; B) Nanostructured cellulosic films.

Figura 1. A) Celulose nanofibrilada; B) Filmes nanoestruturados de celulose.

Microscopic characterization

Scanning electron microscopy (SEM) analysis allowed observation of the structures and dimensions of Eucalyptus sp. pulp used to obtain nanofibrillated cellulose (Figure 2). The fibers presented average diameters around $12.00 \mu \mathrm{m}$ and length reaching up to tens of millimeters (Figure 2). 




B

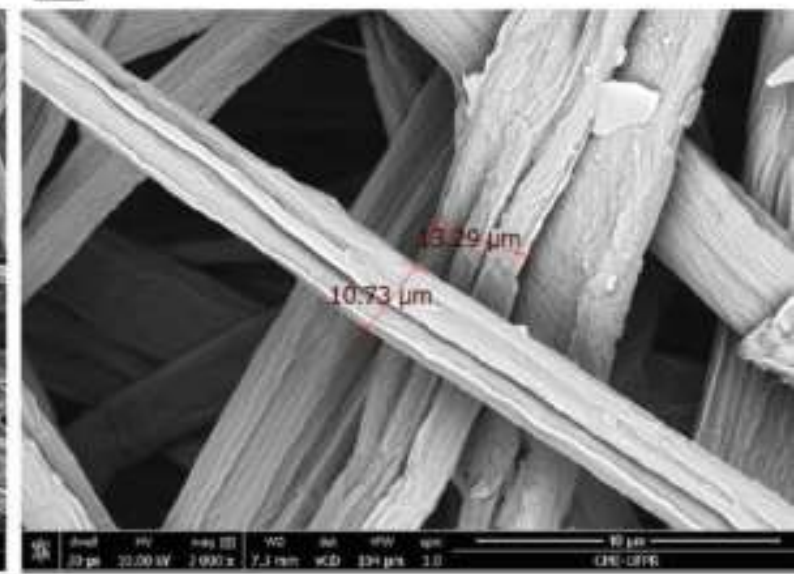

Figure 2. Images of Eucalyptus sp. fibers obtained by scanning electron microscopy (SEM) A) Increase of 500 times / $100 \mu \mathrm{m}$ Scale. B) Increase $2 \mathrm{k}$ times / Scale $40 \mu \mathrm{m}$.

Figura 2. Imagens das fibras de Eucalyptus sp. obtidas por microscopia eletrônica de varredura (MEV) A) Aumento 500 vezes / Escala $100 \mu \mathrm{m}$. B) Aumento $2 \mathrm{k}$ vezes / Escala $40 \mu \mathrm{m}$.

Transmission electron microscopy (TEM) analysis showed the nanofibrils in the three treatments and their fibrillary conformation (Figure 3), confirming the obtainment of nanofibrillated cellulose by mechanical defibrillation in the grinder.


FLORESTA, Curitiba, PR, v. 50, n. 1, p. 897 - 904 , jan/mar 2020 
Figure 3. TEM images of cellulose nanofibrils obtained by A) 2 passes, increase $4 \mathrm{k}$ times / Scale $2 \mu$. B) 2 passes, increase $10 \mathrm{k}$ times / Scale $500 \mathrm{~nm}$ (width of fibers). C) 10 passes, increase $4 \mathrm{k}$ times / Scale $2 \mu$. D) 10 passes, increase 10k times / Scale $500 \mathrm{~nm}$ (width of fibers). E) 20 passes increase 4k times / Scale $2 \mu$. F) 20 passes, increase 10k times / Scale $500 \mathrm{~nm}$ (width of fibers).

Figura 3. Imagens de nanofibrilas de celulose obtidas por microscopia eletrônica de transmissão (MET) A) 2 passes, aumento $4 \mathrm{k}$ vezes / Escala $2 \mu$. B) 2 passes, aumento $10 \mathrm{k}$ vezes / Escala $500 \mathrm{~nm}$ (largura das fibras). C) 10 passes, aumento $4 \mathrm{k}$ vezes / Escala $2 \mu$. D) 10 passes, aumento $10 \mathrm{k}$ vezes / Escala $500 \mathrm{~nm}$ (largura das fibras). E) 20 passes aumento $4 \mathrm{k}$ vezes / Escala $2 \mu$. F) 20 passes, aumento 10k vezes / Escala $500 \mathrm{~nm}$ (largura das fibras).

The values corresponding to the diameters of cellulose nanofibrils ranged from 21 to $44 \mathrm{~nm}$ for nanofibrillated cellulose obtained with 2, 10 and 20 passes, respectively. With nanofibrillated cellulose defined as structures with diameters smaller than $100 \mathrm{~nm}, 2$ passes through the grinder were sufficient to form these structures.

Crystallinity index

Crystallinity indices observed for cellulose and nanofibrillated cellulose of Eucalyptus sp. are presented in Table 1. The values ranged from 67.44 to $78.57 \%$ for cellulose and NFC obtained from 20 passes, respectively. There was a decrease in the crystallinity index values with increase of the mechanical defibrillation process intensity applied to the fibers. The mean values by the Tukey test allowed the formation of four different statistical groups.

Table 1. Mean values and standard deviations of the crystallinity index of cellulose and nanofibrillated cellulose.

Tabela 1. Valores médios e desvios padrão do índice de cristalinidade da celulose e celulose nanofibrilada

\begin{tabular}{ccc} 
Treatment & \multicolumn{2}{c}{ Crystallinity index (\%) } \\
\cline { 2 - 3 } Cellulose & $\overline{\boldsymbol{X}}$ & $\boldsymbol{\sigma}$ \\
\hline Nanofibrillated Cellulose 2 passes & $78.57 \mathrm{a}$ & 1.00 \\
Nanofibrillated Cellulose 10 passes & $73.48 \mathrm{~b}$ & 0.55 \\
Nanofibrillated Cellulose 20 passes & $69.98 \mathrm{c}$ & 0.31 \\
\hline
\end{tabular}

LEGEND: $\bar{X} \bar{X}$ corresponds to the mean and $\sigma$ corresponds to the standard deviation. Different letters show significant difference (p $<0.05$ ) by the Tukey test.

The reduction in the cellulose crystallinity index with the higher number of grinder passes shows that the defibrillation process caused damage to the cellulose crystalline structure, causing degradation to parts of this region, as also observed by Kalia et al. (2014).

The crystallinity curve of Eucalyptus sp. and the nanofibrillated cellulose obtained from the different grinder pass numbers is shown in Figure 4.

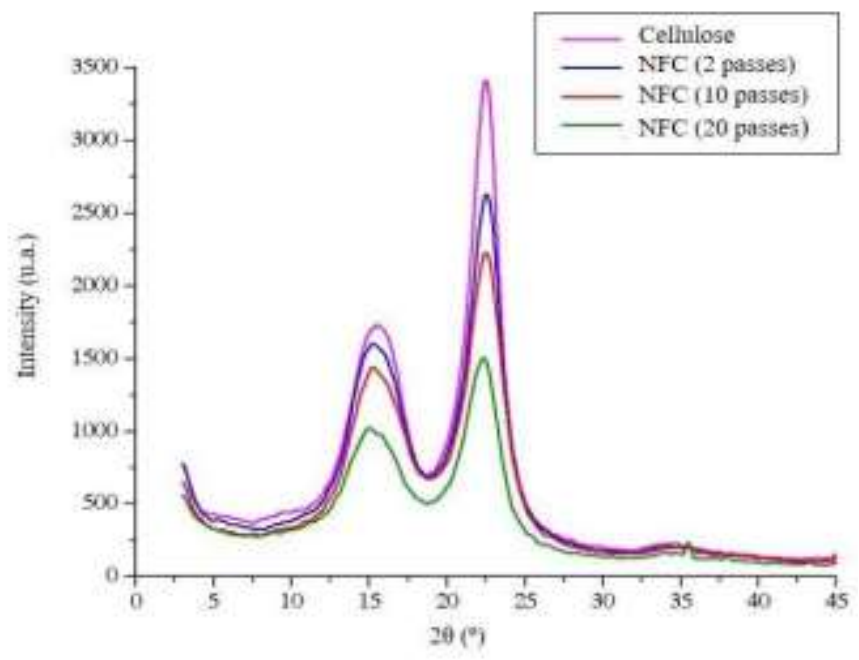

FLORESTA, Curitiba, PR, v. 50, n. 1, p. 897 - 904, jan/mar 2020.

Lopes, M. S. et.al.

ISSN eletrônico 1982-4688 
Figure 4. X-ray diffraction of the nanofibrillated cellulose with different numbers of passes.

Figura 4. Difratograma de raios-X da celulose e celulose nanofibrilada com diferentes números de passes.

The cellulose crystallinity curve has two peaks: one with lower intensity located in the $2 \Theta$ region of $15^{\circ}$ and the other with higher intensity in the $2 \Theta$ region of $22^{\circ}$, as can be seen in Figure 4 . The amorphous halo is located between the angles $18^{\circ} \leq 2 \theta \leq 19^{\circ}$. The highest intensity peak represents the crystalline portion, i.e., the cellulose was more crystalline the larger was the peak in the $2 \Theta$ region of $22^{\circ}$. It can be observed that pulp that did not undergo mechanical defibrillation presented the most intense crystalline peak, and the intensity of the crystalline peaks declined with increasing number of passes.

Viscosity

The viscosity of Eucalyptus sp. pulp and NFC decreased with increasing number of mechanical defibrillation passes (Table 2).

Table 2. Mean values and standard deviations of the viscosity of cellulose and nanocellulose.

Tabela 2. Valores médios e desvios padrão da viscosidade da celulose e nanocelulose.

\begin{tabular}{ccc} 
Treatment & Viscosity (mPa.s) \\
\cline { 2 - 3 } Cellulose Eucalyptus sp. & $\overline{\boldsymbol{X}}$ & $\boldsymbol{\sigma}$ \\
\hline Nanofibrillated Cellulose 2 passes & $48,63 \mathrm{a}$ & 2,07 \\
Nanofibrillated Cellulose 10 passes & $36,77 \mathrm{~b}$ & 2,03 \\
Nanofibrillated Cellulose 20 passes & $14,83 \mathrm{c}$ & 0,02 \\
\hline
\end{tabular}

LEGEND: $\overline{\bar{X}} \bar{X}$ corresponds to mean and $\sigma$ corresponds to standard deviation. Different letters show significant difference (p <0.05) by the Tukey test.

Viscosity is influenced by the level of cellulose degradation due to chemical and physical processes, such as pulping, delignification and mechanical defibrillation, and the degree of polymerization of the chains. Therefore, the results showed that mechanical defibrillation significantly influenced the reduction of cellulose viscosity, generating four distinct statistical groups.

Due to the separation of the cellulose fibrils during the mechanical defibrillation process, as observed in the micrographs of nanofibrillated cellulose obtained by TEM, occurred a reduction in the size of the cellulose molecules, significantly and negatively affecting their degree of polymerization, as can be observed by the drop in viscosity values.

\section{DISCUSSION}

According to Besbes et al. (2011), the mechanical method of nanocellulose production leads to the production of a gel with high water content, as verified in this study (Figure 1). Regarding fiber diameter, Boschetti et al. (2015), when studying the characteristics of wood fibers from a Eucalyptus grandis x Eucalyptus urophylla clone, found an average fiber diameter value of $15 \mu \mathrm{m}$. In this work, the SEM images demonstrated fibers with an approximate average diameter of $12.00 \mu \mathrm{m}$ (Figure 2).

SEM and TEM images comparison revealed that the fiber dimensions decreased considerably after the defibrillation process using the grinder. Henriksson et al. (2008) observed that the mechanical process of obtaining nanofibrillated cellulose markedly changed the size of the cellulose fibers, since the process promotes the defibrillation of the wood cell wall, exposing the cellulose fibrils and microfibrils.

Yano and Nakagaito (2004) observed that the mechanical process of obtaining nanofibrillated cellulose can actually modify the structural and surface properties, forming a nano network through the intertwining of nanofibrils due to the greater exposure of their active sites.

Regarding the average diameter found for cellulose nanofibrils (approximately $30 \mathrm{~nm}$ ), no differences were observed in function of the number of passes. The mechanical defibrillation of the fiber cell wall resulted in obtaining nanofibrillated cellulose and exposure of structures with diameter smaller than the fibers, consisting of 
microfibril aggregates (MISSOUM et al. 2013). Defibrillation exposed the innermost layers and increasing the binding potential in NFC. Comparison of the images obtained by SEM (Figure 2) with those obtained by TEM (Figure 3) indicates dimensional reduction of cellulose fibers.

Other authors have also observed the same trend, such as Wang et al. (2013), who obtained cellulose nanofibrils with diameters between 30 and $100 \mathrm{~nm}$ after 20 passes through a grinder at $1600 \mathrm{rpm}$ and consistency of $1 \%$.

In this study, the internal and external fiber defibrillation caused a reduction of crystallinity and viscosity with increase in the number of grinder passes. Hai et al. (2013) also observed that mechanical defibrillation treatment promotes irreversible fiber changes, such as reduced crystallinity and viscosity, due to internal and external fibrillation phenomena.

Also regarding crystallinity, in a study of the properties of nanofibrillated cellulose, Iwamoto et al. (2007) noted that the crystallinity index decreased with increasing number of passes (1, 3, 5, 9, 15 and 30 passes), suggesting that the crystalline regions' structures were degraded due to the defibrillation process, as occurred in this study. Tonoli et al. (2012) observed the same trend of reduction in crystallinity index (from 69 to $60 \%$ ) in a study with Eucalyptus kraft pulp subjected to mechanical defibrillation.

In other viscosity studies, Iwamoto et al. (2007) observed, after mechanical defibrillation treatment, a reduction in viscosity. The reduction in cellulose viscosity due to mechanical defibrillation treatment has also been observed by other authors, such as Zimmermann et al. (2010), who found a reduction between $15 \%$ and $63 \%$ in viscosity due to mechanical fibrillation, in a study of the properties of nanocellulose obtained from different raw materials, and Pöhler et al. (2010), who observed loss of viscosity in a study of the influence of fibrillation methods on the characteristics of cellulose nanofibrils.

\section{CONCLUSIONS}

- The results of this work indicate it was possible to obtain nanofibrillated cellulose (NFC) from mechanical processing of Eucalyptus sp. pulp in a colloid grinder using 2, 10 and 20 passes;

- Transmission electron microscopy analysis showed no differences in NFC structure and dimensions for the different numbers of passes. The nanofibrils had diameters ranging from 21 to $44 \mathrm{~nm}$;

- For the tests of crystallinity and viscosity indexes, the values found showed a reduction in these parameters with increasing number of passes through the colloidal grinder. The results indicated that the mechanical defibrillation process attacked the crystalline regions of cellulose and reduced the degree of polymerization of cellulose chains.

\section{REFERENCES}

ABDUL KHALIL, H. P. S.; DAVOUDPOURA, Y.; NAZRUL ISLAM, M.; MUSTAPHA, A.; SUDESH, K.; DUNGANIA, R.; JAWAID, M. Production and modification of nanofibrillated cellulose using various mechanical processes: A review. Carbohydrate Polymers, v.99, n. 2, p. 649-665, 2014.

BALEA, A.; MERAYO, N.; FUENTE, N.; NEGRO, C.; DELGADO-AGUILAR, M.; MUTJE, P.; BLANCO, A. Cellulose nanofibers from residues to improve linting and mechanical properties of recycled paper. Cellulose, v. 25, p. 1339-1351, 2018.

BESBES, I.; VILAR M.R.; BOUFI, S. Nanofibrillated cellulose from alfa, eucalyptus and pine fibres: preparation, characteristics and reinforcing potential. Carbohydrate Polymers, v.86 (3), p.1198-1206, 2011.

BOSCHETTI, W.; NETO, T.; PAES, J. B.; OLIVEIRA, J. T. S.; DUDECKI, L. Características anatômicas para produção de celulose do lenho de reação de árvores inclinadas de eucalipto. Pesquisa Agropecuária Brasileira, v.50, n.6, p. 459-467, 2015.

BRINCHI, L.; COTANA E. FORTUNATI, J.M. Kenny Production of nanocrystalline cellulose from lignocellulosic biomass: Technology and applications Carbohydrate Polymer, v. 94, p. 154-169, 2013.

BRODIN, F. W.; GREGERSEN, O. W.; SYVERUD, K. Cellulose nanofibrils: Challenges and possibilities as a paper additive or coating material. Nordic Pulp \& Paper Research Journal, v.29, n. 1, p. 156-166, 2014.

CHING, Y.C.; RAHMAN, A.; CHING, K.Y.; SUKIMAN, N.L.; CHENG, H.C. Preparation and Characterization of Polyvinyl Alcohol-Based Composite Reinforced with Nanocellulose and Nanosilica. BioResources, v.10 (2), p.3364-3377, 2015.

FLORESTA, Curitiba, PR, v. 50, n. 1, p. 897 - 904, jan/mar 2020.

Lopes, M. S. et.al.

ISSN eletrônico 1982-4688

DOI: 10.5380/rf.v50 i1.58690 
ELIZONDO, E.; VECIANA, J.; VENTOSA, N. Nanostructuring molecular materials as particles and vesicles for drug delivery, using compressed and supercritical fluids. Nanomedicine, v.7, n. 9, p. 1391-1408, 2012.

FRANCO, T.S.; POTULSKI, D.C.; VIANA, L.C.; FORVILlE, E.; ANDRADE, A.S. MUNIZ, G.I.B. Nanocellulose obtained from residues of peach palm extraction (Bactris gasipaes). Carbohydrate Polymers, v.218, p. 8-19, 2019.

HAI, L. V.; PARK, H. J.; SEO, Y. B. Effect of PFI mill and Valley beater refining on cellulose degree of polymerization, alpha cellulose contents, and crystallinity of wood and cotton fibers. Journal of Korea TAPPI, v. 45 , n. 4, p.27-33, 2013.

HENRIKSSON, M; BERGLUND, L. A.; LINDSTRÖM, T.; NISHINO, T. Cellulose Nanopaper Structures of High Toughness. Biomacromolecules, v. 9, n. 6, p. 1579-1585, 2008.

HERRERA, M.A.; SIRVIÖ J.A.; MATHEW, A.P.; OKSMAN, K. Environmental friendly and sustainable gas barrier on porous materials: nanocellulose coatings prepared using spin- and dip-coating. Materials \& Design, v.93, p. 19-25, 2016.

IWAMOTO, S.; NAKAGAITO, A. N.; YANO, H. Nano-fibrillation of pulp fibers for the processing of transparent nanocomposites. Applied Physics A, v. 89, n. 2, p. 461-466, 2007.

KARGARZADEH, H.; MARIANO, M.; HUANG, J.; LIN, N.; AHMAD, I.; DUFRESNE. Recent developments on nanocellulose reinforced polymer nanocomposites: a Review. Polymer, v.132, p. 368-393, 2017.

MISSOUM, K.; BELGACEM, M.N.; BRAS, J. Nanofibrillated Cellulose Surface Modification: A Review. Materials, v. 6, p.1745-1766, 2013.

NAKAGAITO, A. N.; FUJIMURA, A.; SAKAI, T.; HAMA, Y.; YANO, H. Production of microfibrillated cellulose (MFC)-reinforced polylactic acid (PLA) nanocomposites from sheets obtained by a papermaking-like process. Composites Science and Technology, v. 69, n. 7-8, p. 1293-1297, 2009.

PÖHLER, T.; LAPPALAINEN, T.; TAMMELIN, T.; ERONEN, P.; HIEKKATAIPALE, P.; VEHNIÄINEN, A.; KOSKINEN, T. M.. Influence of fibrillation method on the character of nanofibrillated cellulose (NFC). VTT Technical Research Centre of Finland. The Finnish Centre for Nanocellulosic Technologies, Finland. 2010.

POTULSKI, D. C.; VIANA, L. C.; MUNIZ, G. I. B.; ANDRADE, A. S.; KLOCK, U. Caracterização de nanofilmes de celulose nanofibrilada obtida em diferentes consistências. Scientia Forestalis, v. 44, n. 110, p. 361372, 2016.

SEGAL, L.; CREELY, J. J.; MARTIN, A. E.; CONRAD, C. M. An empirical method for estimating the degree of crystallinity of native cellulose using the X-ray diffractometer. Textile Research Journal, v. 29, n. 10, p. 786-794, 1959.

TECHNICAL ASSOCIATION OF THE PULP AND PAPER INDUSTRY - TAPPI. T220-om01. Physical testing of pulp handsheets. In: Tappi Test Methods. TAPPI Press, Norcross, GA, 2004.

TONOLI, G. H. D.; TEIXEIRA, E. M.; CORRÊA, A. C.; MARCONCINI, J. M.; CAIXETA, L. A.; PEREIRA DA SILVA, M. A.; MATTOSO, L. H. C. Cellulose micro/nanofibres from Eucalyptus kraft pulp: Preparation and properties. Carbohydrate Polymers, n. 89, n. 1, p.80-88, 2012.

VIANA, L.C.; POTULSKI, D.C.; MUNIZ, G.I.B.; ANDRADE, A.S.; SILVA, E.L. Nanofibrillated cellulose as an additive for recycled paper. Revista Cerne, v.24, n.2, p.140-148, 2018.

WANG, H.; LI, D.; ZHANG, R. Preparation of Ultralong Cellulose Nanofibers and Optically Transparent Nanopapers Derived from Waste Corrugated Paper Pulp. Bioresources, v. 8, n. 1, p. 1374-1384, 2013.

YANO H.; NAKAGAITO A. N. The effect of morphological changes from pulp fiber towards nano-scale fibrillated cellulose on the mechanical properties of high-strength plant fiber based composites. Applied Physics A - Materials Science \& Processing, v. 78, n. 4, p. 547-552, 2004.

ZIMMERMANN, T.; BORDEANU, N.; STRUB, E. Properties of nanofibrillated cellulose from different raw materials and its reinforcement potential. Carbohydrate Polymers, n. 79, n. 4, p. 1086-1093, 2010. 